\title{
Ceria-Based Mixed Oxide Supported Cu0: An Efficient Heterogeneous Catalyst for Conversion of Cellulose to Sorbitol
}

\author{
Bashir Ahmad Dar1,2,3*, Sara Khalid², Tariq Ahmad Wani', Mushtaq Ahmad Mir³, \\ Mazahar Farooqui ${ }^{3}$ \\ ${ }^{1}$ Indian Institute of Integrative Medicine (CSIR), Jammu, India \\ ${ }^{2}$ Indian Institute of Chemical Technology (CSIR), Hyderabad, India \\ ${ }^{3}$ Post Graduate and Research Center, Maulana Azad College, Aurangabad, India \\ Email: ${ }^{*}$ bashir 15 dar@yahoo.com
}

Received 18 January 2015; accepted 8 February 2015; published 11 February 2015

Copyright (C) 2015 by authors and Scientific Research Publishing Inc.

This work is licensed under the Creative Commons Attribution International License (CC BY). http://creativecommons.org/licenses/by/4.0/

c) (i) Open Access

\begin{abstract}
A series of $\mathrm{CeO}_{2}-\mathrm{Al}_{2} \mathrm{O}_{3}, \mathrm{CeO}_{2}-\mathrm{TiO}_{2}, \mathrm{CeO}_{2}-\mathrm{ZrO}_{2}$, and $\mathrm{CeO}_{2}-\mathrm{SiO}_{2}$ mixed-oxide supported copper catalysts were prepared by a modified deposition-precipitation method from ultra dilute aqueous solutions and were investigated for hydrogenolysis of cellulose in aqueous medium, in the presence of hydrogen to produce sorbitol as major product. Among all the catalysts tested in the present work, $\mathrm{CuO} / \mathrm{CeO}_{2}-\mathrm{ZrO}_{2}$ catalyst proved to be the most promising with high conversion $(92 \%)$ and excellent selectivity (sorbitol 99.1\%), at an intermediate reaction temperature of $245^{\circ} \mathrm{C}$ in a neutral aqueous solution without an aid of liquid phase acid. The catalyst was recyclable in repeated runs and no deactivation was observed even after five reaction cycles. $\mathrm{CuO} / \mathrm{CeO}_{2}-\mathrm{ZrO}_{2}$ has been characterized by XRD, SEM, TPR and BET surface area techniques.
\end{abstract}

\section{Keywords}

Biomass, Copper, Supported Catalyst, Hydrogenolysis, Sorbitol, Ceria

\section{Introduction}

The rapid depletion of petroleum reserves and growing concerns about global climate change have attracted immense attention towards alternative fuel production pathways based on renewable resources, such as biomassderived carbohydrates [1]. Cellulose is one of the most abundant sources of biomass and is a polymer of D-

\footnotetext{
*Corresponding author.
}

How to cite this paper: Dar, B.A., Khalid, S., Wani, T.A., Mir, M.A. and Farooqui, M. (2015) Ceria-Based Mixed Oxide Supported CuO: An Efficient Heterogeneous Catalyst for Conversion of Cellulose to Sorbitol. Green and Sustainable Chemistry, 5, 15-24. http://dx.doi.org/10.4236/gsc.2015.51003 
glucose with glucose units joined together through $\beta$-1,4-glycosidic bonds. The abundant functional groups $(\mathrm{OH}$ groups) of cellulose make it an ideal feedstock for sustainable production of chemicals [2]. Nevertheless, the extensive hydrogen-bonding networks and the high crystallinity of cellulose make it resistant to chemical and enzymatic degradation. Great efforts have been devoted to the cellulose transformation in various ways, such as fermentation with enzyme, photochemical conversion, hydrolysis with acid catalysts, pyrolysis at high temperatures, and etherification with alcohols [3]-[10]. All these conventional methods for conversion of cellulose to value added products have some serious drawbacks such as slow reaction rate, difficult separation of products and catalysts, corrosion hazards, harsh conditions and generation of large amount of neutralisation waste [11]. Heterogeneous catalysis has advantages to overcome these drawbacks. Conversion of cellulose with solid catalysts (heterogeneous catalysts) under hydrothermal conditions is a green and efficient process for the sustainable production of chemicals, in which several consecutive reactions proceed in one reactor and cooperate well. Hydrogenolysis of cellulose resulting in $\mathrm{C}-\mathrm{C}$ and $\mathrm{C}-\mathrm{O}$ cleavage is a promising technology for the direct conversion of biomass into commodity chemicals and therewith, an entry point for future biorefinery models [12]-[14]. Surprisingly, few studies on hydrogenolysis of cellulose exist and were carried out at rather high reaction temperatures. Current investigations aim at the development of solid heterogeneous catalysts to overcome the need for costly homogeneous catalysts for conversion of cellulose to commodity chemicals [15]. Hydrolysis of cellulose to glucose followed by hydrogenation of glucose to sorbitol in single pot using a bifuntional heterogeneous catalyst seems an advanced method.

Sorbitol is used as a sweetener in diet foods and pharmaceutical tablets because of its low calorie value. It is a potential raw material for the synthesis of variety of value-added chemicals such as isosorbide, 1,4-sorbitan, glycols, glycerol, lactic acid and L-sorbose [16]. Isosorbide is used to increase the glass transition point of polyethylene terephthalate (PET) which helps to store hot drinks in PET bottles. L-sorbose is a precursor to vitamin C [17]. Dumesic and co-workers have reported that hydrogen for fuel cell could be produced from sorbitol over supported metal catalysts with high selectivity compared with glucose [18]. The C5-C6 hydrocarbons are also formed from sorbitol [19]. Sorbitol can also be fermented to ethanol via enzymatic dehydrogenation [20]. Thus, sorbitol is selected as one of the 12 top value-added products from biomass in the US DOE report [21].

In continuation of our work on environment friendly chemical transformations [21]-[26], we herein, report copper supported on ceria-zirconia as a highly stable catalyst for direct and selective hydrogenolysis of cellulose to sorbitol. To the best of our knowledge, this catalytic system has not been reported yet for the hydrgenolysis of cellulose and is one of the best performances of heterogeneous catalysts ever reported.

$\mathrm{CeO}_{2}$ found extensive applications in catalysis, in particular due to its reducible character, and improved surface metals dispersion [27]. The redox chemistry $\left(\mathrm{Ce}^{3+} / \mathrm{Ce}^{4+}\right)$ of doped cerium oxides is sensitive to crystal structure defects [28]. The replacement of cerium ions by cations of different size and/or charge modifies ionic mobility within the lattice resulting in the formation of a defective fluorite structured solid solution [29]. The acidity of ceria mixed oxides also increases with the addition of cations like $\mathrm{Zr}^{4+}$ thus helps in the breakdown of cellulose to its monomers [30]. This concept was used to prepare different ceria based mixed oxide supports for copper catalyst for one hydrogenolysis (hydrolysis followed by hydrogenation). The reaction scheme of cellulose hydrogenolysis is illustrated in Scheme 1.

\section{Experimental}

\subsection{Catalyst Preparation}

The catalyst was prepared in two steps.

The first step involves preparation of catalyst supports and to accomplish this reported method was followed [25] [26]. A solution containing $\mathrm{Ce}\left(\mathrm{NO}_{3}\right)_{3} \cdot 6 \mathrm{H}_{2} \mathrm{O}(9.314 \mathrm{~g})$ and $\mathrm{SiO}\left(\mathrm{NO}_{3}\right)_{2}(3.6052 \mathrm{~g})$ is treated with a solution of $\mathrm{NH}_{4} \mathrm{OH}$ at constant $\mathrm{pH} 9.0$ and room temperature with constant stirring using mechanical stirrer. The resulting

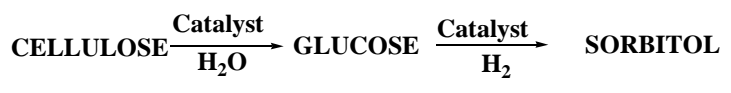

Scheme 1. Ceria-based mixed oxide supported $\mathrm{CuO}$ catalysed conversion of cellulose to sorbitol. 
precipitates were aged at room temperature for $12 \mathrm{~h}$, then filtered and washed until the complete removal of nitrate ions. The washed precipitate is dried at $100^{\circ} \mathrm{C}$ and calcined under air at $500^{\circ} \mathrm{C}$ for 5 h. The support prepared in this way is Ceria-Silica and is denoted as CS. Ceria-titania (CT) was prepared in a similar manner using solution containing $8.6112 \mathrm{~g} \mathrm{Ce}\left(\mathrm{NO}_{3}\right)_{3} \cdot 6 \mathrm{H}_{2} \mathrm{O}$ and $3.7276 \mathrm{~g} \mathrm{TiO}\left(\mathrm{NO}_{3}\right)_{2}$ : Ceria-Zirconia (CZ) by using $7.3004 \mathrm{~g}$ $\mathrm{Ce}\left(\mathrm{NO}_{3}\right)_{3} \cdot 6 \mathrm{H}_{2} \mathrm{O}$ and $3.915 \mathrm{~g} \mathrm{ZrO}\left(\mathrm{NO}_{3}\right)_{2}$ and Ceria-alumina (CA) by using $7.9169 \mathrm{~g} \mathrm{Ce}\left(\mathrm{NO}_{3}\right)_{3} \cdot 6 \mathrm{H}_{2} \mathrm{O}$ and 6.8432 $\mathrm{g} \mathrm{Al}\left(\mathrm{NO}_{3}\right)_{3} \cdot 9 \mathrm{H}_{2} \mathrm{O}$ following the procedure similar to that for the preparation of Ceria-Silica. All solid supports are in the 1:1 molar ratio for $\mathrm{Ce}_{2} \mathrm{O}_{3}: \mathrm{M}_{2} \mathrm{O}_{3}$.

The second step involves impregnation of copper oxide on to the support for the preparation of the catalysts like $\mathrm{Cu} / \mathrm{CS}, \mathrm{Cu} / \mathrm{CZ}, \mathrm{Cu} / \mathrm{CT}$ and $\mathrm{Cu} / \mathrm{CA}$. To impregnate the copper oxide (10 wt\%), adequate amounts of aqueous $\mathrm{Cu}\left(\mathrm{NO}_{3}\right)_{2} \cdot 3 \mathrm{H}_{2} \mathrm{O}$ solutions were used. To this aqueous solution, the finely powdered mixed oxide (support) was separately added. The excess water was gradually evaporated on a hot-water bath under constant mechanical agitation and subsequently dried at $110^{\circ} \mathrm{C}$ for $12 \mathrm{~h}$. Finally, the obtained materials were calcined at $500^{\circ} \mathrm{C}$ for $5 \mathrm{~h}$ in a closed electrical furnace.

\subsection{Catalytic Performance Tests}

Avicil cellulose (500 mg), $10 \mathrm{wt} \% \mathrm{Cu} / \mathrm{CZ}$ (200 mg), and distilled water $(50 \mathrm{~mL}$ ) were charged in a $1 \mathrm{~L}$ stainless steel Parr 4521M (Moline, IL) pressure reactor controlled with a Parr 4843 temperature controller equipped with an overhead stirrer and a pressure transducer. It was pressurized with $\mathrm{H}_{2}$ gas of 750 PSI. The reactor was heated to $245^{\circ} \mathrm{C}$ and maintained at this temperature with constant stirring at $1000 \mathrm{rpm}$ for $240 \mathrm{~min}$. After completion of the reaction, the reactor was cooled to room temperature, and the liquid part was separated by centrifugation, and then filtered through whatman filter paper. The solution containing the water-soluble products was analyzed by HPLC with Hypersil $\mathrm{NH}_{2} 5 \mu \mathrm{m}$ column at $25^{\circ} \mathrm{C}$, Shimadzu LC-20AT pump, and Shimadzu RID-10A detectors at $40^{\circ} \mathrm{C}$. Acetonitrile/water solution $(75 / 25 \mathrm{~V} / \mathrm{V})$ was used as mobile phase at $0.8 \mathrm{~mL} / \mathrm{min}$. Sorbitol and manitol were characterized by comparing their HPLC profile with the standard samples and their percentage concentration in each sample was calculated from the peak area distribution (HPLC graph) using external standard method. The conversion of cellulose was determined from the weight difference of the solid residue after the reaction. After finishing the reaction with the fresh catalyst, the reaction mixture was centrifuged and the residue was separated from the liquid part. The residue, which contained the recovered catalyst and the un-reacted cellulose, was used for the next reaction cycle without any treatment.

\section{Results and Discussion}

\subsection{Catalyst Characterization}

The X-ray diffraction spectrum (XRD) of the catalyst (Cu/CZ) was taken on a Rigaku Miniflex diffractometer, using Ni-filtered $\mathrm{Cu} \mathrm{Ka}(0.15418 \mathrm{~nm})$ radiation source. The sample was scanned over the range $2.00-79.99$ on $2 \theta$ scale with steps $0.011^{\circ}$ and step time $13.6 \mathrm{~s}$. SEM of the sample was carried out using SEM. Hitachi S-520 Japan instrument. The reducibility and BET surface area of catalyst was determined by CHEMBET-3000 TPR/ TPD/TPO instrument, containing a quartz reactor (i.d. $4 \mathrm{~mm}$ ) and a TCD detector. XRD patterns of the $\mathrm{Cu} / \mathrm{CZ}$ in Figure 1 shows small diffraction peaks at $2 \theta=35.6^{\circ}, 38.9^{\circ}$ and $61.5^{\circ}$ are attributed to the crystalline copper oxide (tenorite copper oxide, ICDD PDF 45-0937) [31]. The diffraction lines at $2 \theta=28.9^{\circ}, 33.5^{\circ}, 47.9^{\circ}, 57.3^{\circ}$, $69.8^{\circ}$ and $77.9^{\circ}$ correspond to Ceria. Zirconia shows humps at $33.9^{\circ}, 38.8^{\circ}, 58.2^{\circ}$ and $71.0^{\circ}$ merged with diffraction peaks of Ceria which can occur because of incorporation of zirconium cations into the ceria lattice leading to shrinkage of the lattice [32]-[34].

To study the morphology SEM of sample (Figure 2) was carried out using SEM. Hitachi S-520 Japan instrument. The SEM image is a confirmation for coarse surface (thus elevated surface area), which is able to adsorb substrate and or reagent to a high extent. It is observed that $\mathrm{CuO}$ particles are randomly distributed over the support surface. It should also be noted that $\mathrm{CuO}$ over the support constitutes several aggregates and not a continuous film. The surface morphology of $\mathrm{CuO}$ supported on $\mathrm{CeO}_{2}-\mathrm{ZrO}_{2}$ shows that no separate crystallites of the bulk phase of $\mathrm{CuO}$ were found in the supported sample.

$\mathrm{CuO}$ distribution on supported samples surface was analysed by ICPMS method. The analysis was repeated on different samples in order to ensure the reproducibility of the obtained results. Microanalytcal data of ICPMS analysis show that the amount of $\mathrm{CuO}$ deposited on the support is $8.9 \mathrm{wt} \%$.

To assess the reducibility of the dispersed oxide and the interaction between the supported metal and the support, TPR was performed. This is an important technique for understanding the reduction behavior and thermal 


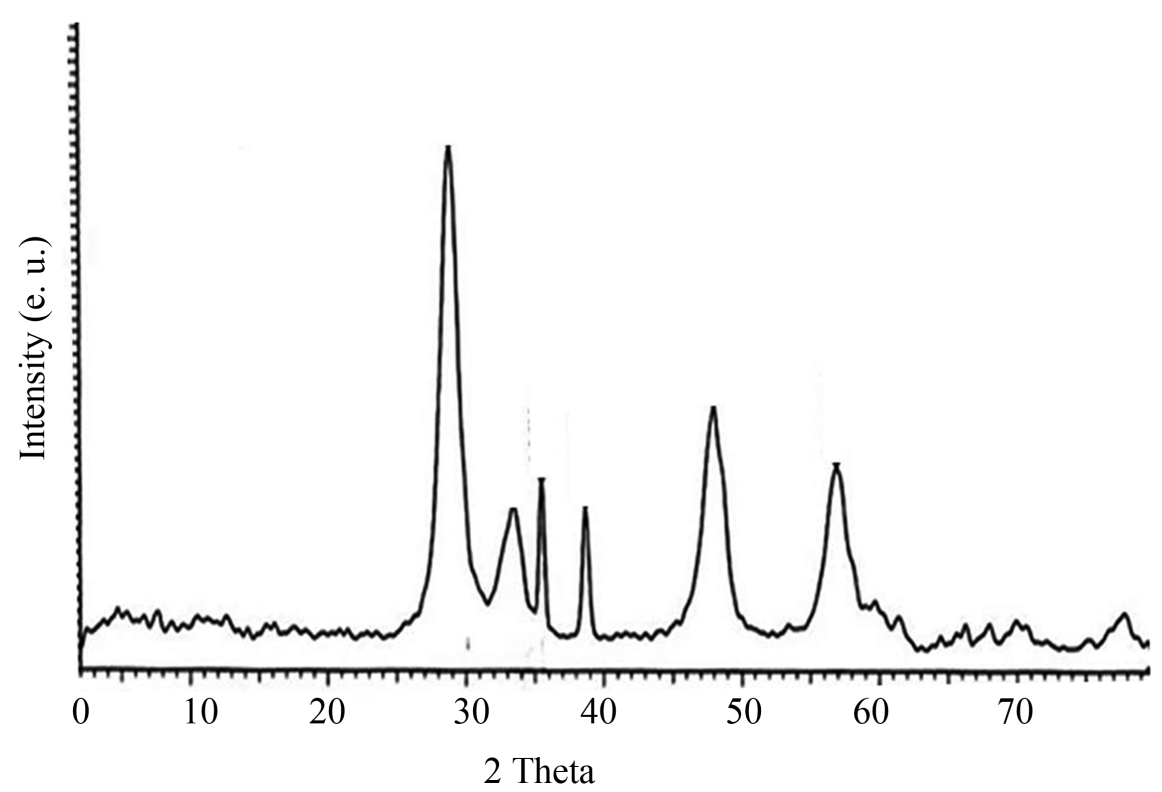

Figure 1. XRD of $\mathrm{Cu} / \mathrm{CZ}$.

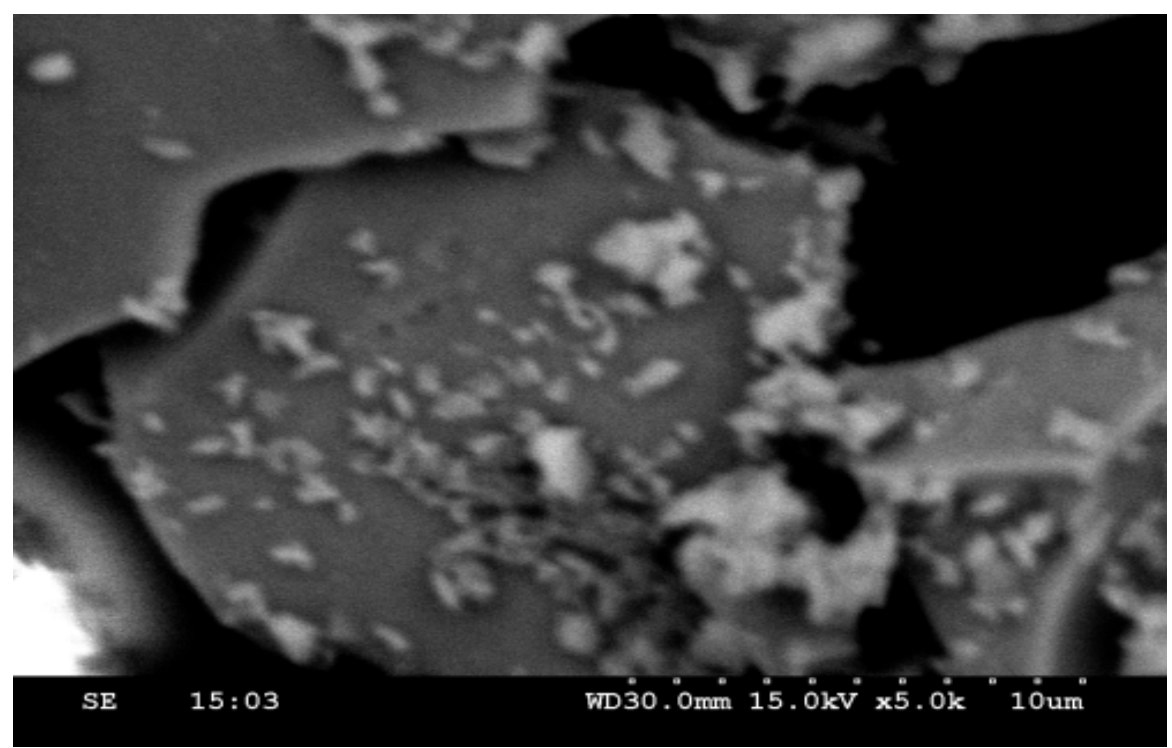

Figure 2. SEM of $\mathrm{Cu} / \mathrm{CZ}$.

stability of the active metal oxide particles. The reducible character of catalyst was determined by CHEMBET$3000 \mathrm{TPR} / \mathrm{TPD} / \mathrm{TPO}$ instrument, containing a quartz reactor (i.d. $=4 \mathrm{~mm}$ ) and a T.C.D. detector. The $\mathrm{H}_{2} \mathrm{TPR}$ curve of the catalyst is depicted in (Figure 3). The $\mathrm{H}_{2}$ consumption patterns reveal that the dispersed copper oxide over the support reduces at a relatively lower temperature than pure $\mathrm{CuO}$. When copper oxide reduces to a certain extent, it tends to dissociate $\mathrm{H}_{2}$ much more easily and then reduces at a higher rate, which is a potential source for the TPR peak at $160^{\circ} \mathrm{C}$. As noted from previous reports, it is not easy to resolve the sequential reduction peaks of copper ( $\mathrm{Cu}^{2+} \rightarrow \mathrm{Cu}^{2+} \rightarrow \mathrm{CuO}$ ) [35]-[37]. However, the observed different features in the TPR profile could be related to structural/ morphological variations in the copper oxide species. In this respect, the TPR profile obtained clearly reveals a higher copper heterogeneity, in agreement with other characterization results described above.

Thus, the presence of several reduction peaks for $\mathrm{CuO} / \mathrm{CeO}-\mathrm{ZrO}_{2}$ must be related to the presence of different copper species in the sample. Avgouropoulos [31], studying the reduction of CuO supported on ceria, attributed a peak at $170^{\circ} \mathrm{C}$ to the reduction of highly dispersed $\mathrm{CuO}$ strongly interacting with the ceria surface and two 


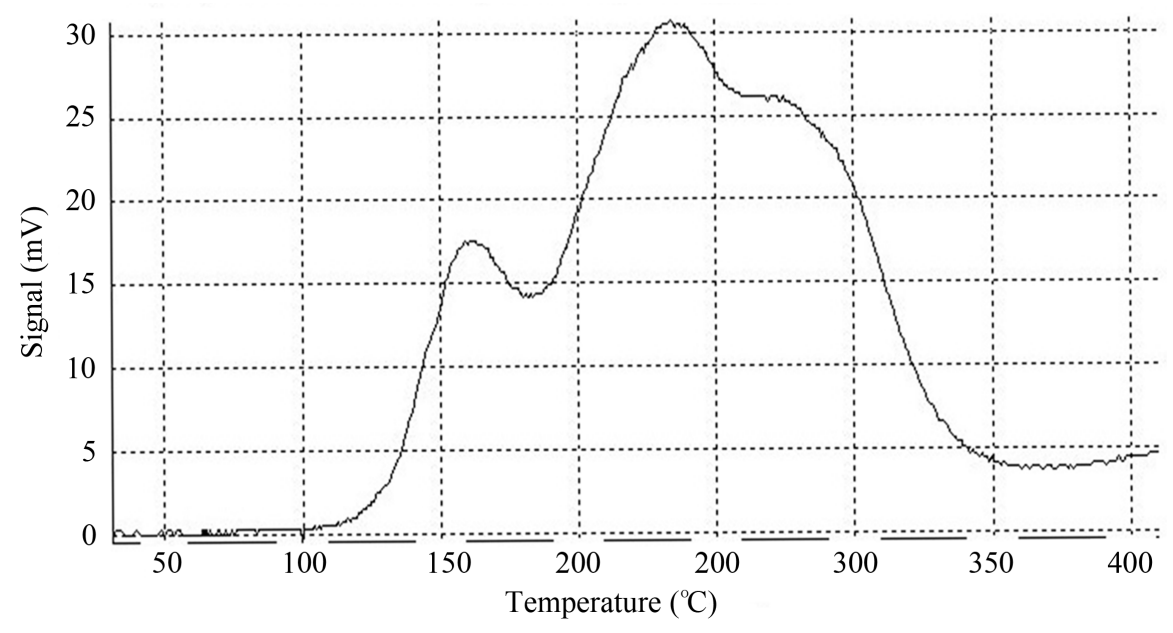

Figure 3. TPR of $\mathrm{Cu} / \mathrm{CZ}$.

peaks at $235^{\circ} \mathrm{C}$ and $275^{\circ} \mathrm{C}$ to the reduction of larger $\mathrm{CuO}$ particles weakly interacting with ceria. A broad reduction peak with a shoulder at low temperature may be attributed to the reduction of highly dispersed copper oxide species interacting with ceria, and a peak at higher temperature assigned to the reduction of bulk-like $\mathrm{CuO}$ [38].

To know the surface area of the catalyst Nitrogen adsorption and desorption was determined at $-196^{\circ} \mathrm{C}$ by means of an automated CHEMBET-3000 adsorption apparatus. Samples were pretreated in high vacuum at $200^{\circ} \mathrm{C}$ for $2 \mathrm{~h}$. The specific surface area of $\mathrm{Cu} / \mathrm{CZ}$ was found to be $112.51 \mathrm{~m}^{2} / \mathrm{g}$.

\subsection{Cellulose Hydrogenolysis}

At the onset of this work, we first screened the different ceria based mixed oxide supported copper catalysts, for conversion of cellulose to sorbitol. The copper loading in all these catalysts was maintained as $10 \mathrm{wt} \%$. Though the conversion of cellulose was not satisfactory (due to un-optimized conditions at the beginning), to our surprise the sorbitol was found as major product with very high selectivity in all the samples (Table 1, entry 1-4). Among the screened catalysts $\mathrm{Cu} / \mathrm{CZ}$ was found to be the most active to give $18 \%$ conversion with $99.9 \%$ selectivity of sorbitol and $0.1 \%$ mannitol (Table 1 , entry 4 ) followed by $\mathrm{Cu} / \mathrm{CS}, \mathrm{Cu} / \mathrm{CT}$ and $\mathrm{Cu} / \mathrm{CA}$.

We proceeded with $\mathrm{Cu} / \mathrm{CZ}$ for further studies and screened this catalyst with different copper loading. $10 \mathrm{wt} \%$ loading copper on $\mathrm{CZ}$ was found to show the optimum results. The conversion of cellulose was found to increase with the increase of catalyst amount from 150 to $300 \mathrm{mg}$ (Table 2). The selectivity of sorbitol was low with $300 \mathrm{mg}$ of catalyst and maximum selectivity was obtained by using $250 \mathrm{mg}$ of catalyst with a little decrease in the cellulose conversion. This decrease in sorrbitol selectivity with increase in catalyst amount may be due to the degradation of the sorbitol under excess catalyst conditions.

The influence of reaction temperature on the catalytic activity of $\mathrm{Cu} / \mathrm{CZ}$ was investigated at constant reaction time to find the optimum conditions for the conversion of cellulose to sorbitol (Table 3). Normally, elevated temperature can contribute to the enhancement of reaction rate and conversion efficiency. We observed that the reaction temperature plays an important role in the reaction process. At $190^{\circ} \mathrm{C}$ of reaction temperature $11 \%$ of cellulose conversion was observed with $99.991 \%$ sorbitol selectivity (Table 3, entry 1). With increase in temperature, conversion of cellulose was found to increase significantly. The optimum temperature thus found was $245^{\circ} \mathrm{C}$ at which $62 \%$ conversion of cellulose was observed with $99.971 \%$ of sorbitol selectivity (Table 3, entry 3). Increasing temperature above $245^{\circ} \mathrm{C}$ could not bring any major increase in cellulose conversion, e.g. at $260^{\circ} \mathrm{C}$ the conversion of cellulose remained at $62 \%$ with a slight decrease in sorbitol selectivity and above this temperature decomposition of sorbitol was observed (Table 3, entry 4).

It is a well known fact that time plays a great role in chemical transformations. In some reactions the yield as well as the selectivity of the desired products increase with increasing reaction time, but sometimes prolonged reaction time leads to the decomposition of the desired product and formation of unwanted side products. At all the above optimized condition we studied the effect of time on the conversion of cellulose and the sorbitol yield. The conversion of cellulose and sorbitol yield increased quickly with increasing the reaction time from 30 min 
to $240 \mathrm{~min}$. 92\% cellulose conversion with $99.081 \%$ sorbitol selectivity was obtained at reaction time of $240 \mathrm{~min}$ (Table 4). No further increase in the cellulose conversion was observed upon increasing the reaction time to 300 min, instead sorbitol content in the sample was found to be lowered to $96.092 \%$ with the extended reaction time (Table 4, entry 4). Hence the optimum reaction temperature and time was set to $245^{\circ} \mathrm{C}$ and 240 min respectively.

Pre-reduction of the catalyst was found to have slight effect on the conversion as well as the sorbitol selectivity (Table 5, entry 2). Conversion of cellulose was found to increase by 3\% with 99.992\% sorbitol yield, but this activity of the reduced catalyst retained for the first cycle only and remaining cycles gave results almost similar to unreduced $\mathrm{Cu} / \mathrm{CZ}$. Since it was difficult to pre-reduce the used catalyst in each cycle, we studied the recyclability of the unreduced catalyst only.

Some of the recently reported catalyst systems and their comparison with that of our finding are illustrated in Table 6. In comparison to the reported results, this method seems much better in terms of cellulose conversion as well as selectivity. In addition to that some of these reported methods require costly catalysts (Table 6, entry 1,3 ) and others give very low selectivity (Table 6 , entry 2,5 ).

Table 1. Effect of catalyst on conversion and sorbitol selectivity.

\begin{tabular}{cccccc}
\hline Entry & Catalyst & Cu loading & Conversion (\%) & Sorbitol (\%) & Mannitol (\%) \\
\hline 1. & $\mathrm{Cu} / \mathrm{CA}$ & $10 \mathrm{wt} \%$ & 10 & 99.917 & 0.083 \\
2. & $\mathrm{Cu} / \mathrm{CT}$ & $10 \mathrm{wt} \%$ & 13 & 99.924 & 0.076 \\
3. & $\mathrm{Cu} / \mathrm{CS}$ & $10 \mathrm{wt} \%$ & 14 & 99.967 & 0.033 \\
4. & $\mathrm{Cu} / \mathrm{CZ}$ & $10 \mathrm{wt} \%$ & 18 & 99.970 & 0.030 \\
5. & $\mathrm{Cu} / \mathrm{CZ}$ & $5 \mathrm{wt} \%$ & 12 & 99.969 & 0.031 \\
6. & $\mathrm{Cu} / \mathrm{CZ}$ & $15 \mathrm{wt} \%$ & 18 & 99.970 & 0.030 \\
\hline
\end{tabular}

Temp. (200 ${ }^{\circ}$ ), Time (30 min), Amount of catalyst (250 mg).

Table 2. Effect of catalyst amount on the cellulose conversion.

\begin{tabular}{ccccc}
\hline Entry & Amount of catalyst (mg) & Conversion (\%) & Sorbitol (\%) & Mannitol (\%) \\
\hline 1. & 150 & 14 & 99.923 & 0.077 \\
2. & 200 & 18 & 99.973 & 0.033 \\
3. & 250 & 18 & 99.970 & 0.030 \\
4. & 300 & 19 & 99.031 & 0.096 \\
\hline
\end{tabular}

Catalyst (Cu/CZ), Temp. (200 C), Time (30 min).

Table 3. Effect of temperature on sorbitol selectivity.

\begin{tabular}{ccccc}
\hline Entry & Temp. $\left({ }^{\circ} \mathrm{C}\right)$ & Conversion (\%) & Sorbitol (\%) & Mannitol (\%) \\
\hline 1. & 190 & 11 & 99.991 & 0.009 \\
2. & 230 & 43 & 99.996 & 0.004 \\
3. & 245 & 62 & 99.971 & 0.029 \\
4. & 260 & 62 & 99.961 & 0.039 \\
\hline
\end{tabular}

Catalyst (Cu/CZ), Amount of catalyst (200 mg), Time (30 min).

Table 4. Effect of time on the conversion of cellulose.

\begin{tabular}{|c|c|c|c|c|}
\hline Entry & Conversion (\%) & Time (min.) & Sorbitol (\%) & Mannitol (\%) \\
\hline 1. & 66 & 60 & 99.961 & 0.039 \\
\hline 2. & 79 & 120 & 99.952 & 0.048 \\
\hline 3. & 92 & 240 & 99.081 & 0.919 \\
\hline 4. & 92 & 300 & 96.092 & 3.908 \\
\hline
\end{tabular}

Catalyst (Cu/Cz), Temp. (200 C), Amount of catalyst (200 mg). 
Table 5. Effect of pre-reduction on activity of $\mathrm{Cu} / \mathrm{CZ}$.

\begin{tabular}{ccccccc}
\hline Entry & Pre-reduction & Conversion $\%$ & Sorbitol \% & Mannitol \% & Temp. ${ }^{\circ} \mathrm{C}$ & Time (min) \\
\hline 1 & No Red. & 92 & 99.081 & 0.919 & 245 & 240 \\
2 & Red. with $\mathrm{H}_{2}$ & 95 & 99.992 & 0.008 & 245 & 240 \\
\hline
\end{tabular}

Reaction conditions: Cu/CZ 200 mg, Cellulose 500 mg, Water 50 ml, pressure 750 PSI, 1000 rpm.

Table 6. Comparison of $\mathrm{Cu} / \mathrm{CZ}$ with reported systems.

\begin{tabular}{cccccccc}
\hline Entry & Catalyst & Conversion $\%$ & Sorbitol $\%$ & Solvent & Temp. ${ }^{\circ} \mathrm{C}$ & Time (min) & Reference \\
\hline 1 & $\mathrm{Ru} / \mathrm{CNT}+$ Phosphoric acid, & 83 & 69 & Water & 185 & $24 \mathrm{~h}$ & {$[40]$} \\
2 & $\mathrm{Cu} / \mathrm{W} / \mathrm{SiO}_{2}-\mathrm{Al}_{2} \mathrm{O}_{3}$ & 89 & 3.5 & Water & 235 & $2 \mathrm{~h}$ & {$[41]$} \\
3 & $\mathrm{Ru} / \mathrm{AC}^{-\mathrm{SO}_{3} \mathrm{H}}$ & 100 & 71.1 & Water & $165^{\circ} \mathrm{C}$ & 36 & {$[42]$} \\
4 & $\mathrm{NiP} / \mathrm{C}$ & 100 & 60 & Water & 230 & 1.5 & {$[43]$} \\
5 & $3 \% \mathrm{Ni}-\mathrm{W}_{2} \mathrm{C} / \mathrm{AC}$ & 86 & 11.3 & Water & 235 & 0.5 & {$[44]$} \\
6 & $\mathrm{Cu} / \mathrm{CZ}$ & 92 & 99.992 & Water & 245 & 240 & This work \\
\hline
\end{tabular}

We observed the degradation of cellulose when the reaction was conducted without using a catalyst. When only CZ support material was used as catalyst, we observed 58.9\% conversion of cellulose and the reaction mixture contained $34.7 \%$ of glucose along with some unidentified products. Evidently, the CZ itself presented notable catalytic activity for hydrolysis of cellulose into sugars. According to Gutierrez-Ortiz et al., strong acid sites markedly increases upon addition of zirconia to the ceria lattice [39]. Interestingly current investigations showed that the combination of cellulose hydrolysis and hydrogenation can significantly improve the conversion of cellulose. These results were found consistent with the results reported by Fukuoka et al. [11] [20]. Thus conversion of cellulose to sorbitol occurs in two steps in a single pot. In the first step the cellulose is converted to glucose which is water soluble. The cleavage of the glycosidic linkages is achieved via addition of water catalyzed by acidic support. In the second step the hydrogenation takes place in presence of catalyst $\mathrm{Cu} / \mathrm{CZ}$ and major product obtained is sorbitol. This appears to be catalyzed by supported metals via dissociation of hydrogen which may spillover on the surface of the support, migrate to Lewis acid sites and release an electron to form protonic acid sites. These sites could consequently act as active sites for acid-catalyzed hydrolysis of cellulose as suggested by Fukuoka et al. [11] [20]. As per this mechanism the results obtained for the optimization of support are in agreement with the acidity of their supports. So decreased conversions of cellulose obtained by using catalyst other than $\mathrm{Cu} / \mathrm{CZ}$ are due to the lower acidity of the supports which provide lower hydrolysis compared to $\mathrm{CeO}_{2}-\mathrm{ZrO}_{2}$. The selectivity of sorbitol is almost similar in all the catalysts used, thus the support of catalyst, time of reaction, amount of catalyst and reaction temperature can be said to have major effects on supported copper catalyzed hydrogenolysis of cellulose to sorbitol.

\subsection{Recyclability of the Catalyst}

The promising activity of the $\mathrm{Cu} / \mathrm{CZ}$ catalyst encouraged us to further investigate its stability during repetitive runs. Long-term stability and reusability of the heterogeneous catalyst are extremely important characteristics for future industrial application to reduce production cost substantially. The recyclability of the catalyst was checked for the cellulose conversion. After the reaction was finished, the spent catalyst was separated from the liquid substance, and reused in a new experiment for the reaction under the same reaction conditions. It was found that the catalyst can be recycled at least 5 times. When the catalyst was reused no obvious decrease of the sorbitol yield was observed in the second run onwards, which indicates the stability of the catalyst.

\section{Conclusion}

We have developed highly active and robust $\mathrm{Cu} / \mathrm{CeO}_{2}-\mathrm{ZrO}_{2}$ catalyst for the direct and selective transformation of cellulose to sorbitol. The high activity of support for cellulose hydrolysis, the mesoporous structure of CZ facilitating reactant transportation, and the enhanced hydrogenation activity of $\mathrm{Cu}$ catalyst are responsible for the excellent performance of $\mathrm{Cu} / \mathrm{CZ}$. By efficiently coupling the hydrolysis reaction and hydrogenation of cellulose, the high yield sorbitol was obtained. This strategy might provide guidance for the cellulosic biomass conversion to polyols in near future. 


\section{References}

[1] Kunkes, E.L., Simonetti, D.A., West, R.M., Serrano-Ruiz, J.C., Gärtner, C.A. and Dumesic, J.A. (2008) Catalytic Conversion of Biomass to Monofunctional Hydrocarbons and Targeted Liquid-Fuel Classes. Science, 322, 417-421. http://dx.doi.org/10.1126/science.1159210

[2] Lichtenthaler, F.W. and Mondel, S. (1997) Perspectives in the Use of Low Molecular Weight Carbohydrates as Organic Raw Materials. Pure \& Applied Chemistry, 69, 1853-1866. http://dx.doi.org/10.1351/pac199769091853

[3] Pang, J., Wang, A., Zheng, M., Zhang, Y., Huang, Y., Chen, X. and Zhang, T. (2012) Catalytic Conversion of Cellulose to Hexitols with Mesoporous Carbon Supported Ni-Based Bimetallic Catalysts. Green Chemistry, 14, 614-617. http://dx.doi.org/10.1039/c2gc16364k

[4] Rinaldi, R. and Schüth, F. (2009) Design of Solid Catalysts for the Conversion of Biomass. Energy \& Environmental Science, 2, 610-626. http://dx.doi.org/10.1039/b902668a

[5] Zhang, Y.H.P. and Lynd, L.R. (2004) Toward an Aggregated Understanding of Enzymatic Hydrolysis of Cellulose: Noncomplexed Cellulase Systems. Biotechnology and Bioengineering, 88, 797-824. http://dx.doi.org/10.1002/bit.20282

[6] Zhang, Y.-H.P., Cui, J., Lynd, L.R. and Kuang, L.R. (2006) A Transition from Cellulose Swelling to Cellulose Dissolution by o-Phosphoric Acid: Evidence from Enzymatic Hydrolysis and Supramolecular Structure. Biomacromolecules, 7, 644-648. http://dx.doi.org/10.1021/bm050799c

[7] Li, C. and Zhao, Z.K. (2007) Efficient Acid-Catalyzed Hydrolysis of Cellulose in Ionic Liquid. Advanced Synthesis and Catalysis, 349, 1847-1850. http://dx.doi.org/10.1002/adsc.200700259

[8] Shimizu, K., Furukawa, H., Kobayashi, N., Itaya, Y. and Satsuma, A. (2009) Effects of Brønsted and Lewis Acidities on Activity and Selectivity of Heteropolyacid-Based Catalysts for Hydrolysis of Cellobiose and Cellulose. Green Chemistry, 11, 1627-1632. http://dx.doi.org/10.1039/b913737h

[9] Sasaki, M., Fang, Z., Fukushima, Y., Adschiri, T. and Arai, K. (2000) Dissolution and Hydrolysis of Cellulose in Subcritical and Supercritical Water. Industrial and Engineering Chemistry Research, 39, 2883-2890. http://dx.doi.org/10.1021/ie990690j

[10] Palkovits, R., Tajvidi, K., Procelewska, J., Rinaldi, R. and Kükrek, M. (2009) For the Hydrogenolysis of Cellulose in Aqueous Media. Chemical Engineering \& Technology, 8, 1046.

[11] Fukuoka, A. and Dhepe, P.L. (2006) Catalytic Conversion of Cellulose into Sugar Alcohols. Angewandte Chemie International Edition, 45, 5161-5163. http://dx.doi.org/10.1002/anie.200601921

[12] Luo, C., Wang, S. and Liu, H. (2007) Cellulose Conversion into Polyols Catalyzed by Reversibly Formed Acids and Supported Ruthenium Clusters in Hot Water. Angewandte Chemie International Edition, 46, 7636-7639. http://dx.doi.org/10.1002/anie.200702661

[13] Sharkov, V.I. (1963) Production of Polyhydric Alcohols from Wood Polysaccharides. Angewandte Chemie International Edition, 2, 405-409. http://dx.doi.org/10.1002/anie.196304051

[14] Palkovits, R., Tajvidi, K., Procelewska, J., Rinaldi, R. and Ruppert, A. (2010) Hydrogenolysis of Cellulose Combining Mineral Acids and Hydrogenation Catalysts. Green Chemistry, 12, 972-978. http://dx.doi.org/10.1039/c000075b

[15] Zhao, H., Kwak, J.H., Wang, Y., Franz, J.A., White, J.M. and Holladay, J.E. (2006) Effects of Crystallinity on Dilute Acid Hydrolysis of Cellulose by Cellulose Ball-Milling Study. Energy and Fuels, 20, 807-811. http://dx.doi.org/10.1021/ef050319a

[16] Wulf, P.D., Soetaert, W. and Vandamme, E.J. (2000) Optimized Synthesis of L-Sorbose by C5-Dehydrogenation of D-Sorbitol with Gluconobacter oxydans. Biotechnology and Bioengineering, 69, 339-343. http://dx.doi.org/10.1002/1097-0290(20000805)69:3<339::AID-BIT12>3.0.CO;2-E

[17] Huber, G.W., Shabaker, J.W. and Dumesic, J.A. (2003) Raney Ni-Sn Catalyst for $\mathrm{H}_{2}$ Production from Biomass-Derived Hydrocarbons. Science, 300, 2075-2077. http://dx.doi.org/10.1126/science.1085597

[18] Davda, R.R. and Dumesic, J.A. (2004) Renewable Hydrogen by Aqueous-Phase Reforming of Glucose. Chemical Communications, No. 1, 36-37. http://dx.doi.org/10.1039/b310152e

[19] Brown, A.T. and Patterson, C.E. (1973) Ethanol Production and Alcohol Dehydrogenase Activity in Streptococcus mutans. Archives of Oral Biology, 18, 127-131. http://dx.doi.org/10.1016/0003-9969(73)90027-7

[20] Dhepe, P.L. and Fukuoka, A. (2007) Cracking of Cellulose over Supported Metal Catalysts. Catalysis Surveys from Asia, 11, 186-191. http://dx.doi.org/10.1007/s10563-007-9033-1

[21] Dar, B.A., Sahu, A.K., Patidar, P., Sharma, P.R., Mupparapu, N., Vyas, D., Maity, S., Sharma, M. and Singh, B. (2012) Heteropolyacid-Clay Nano-Composite as a Novel Heterogeneous Catalyst for the Synthesis of 2,3-dihydro- quinazolinones. Journal of Industrial and Engineering Chemistry, 19, 407-412. http://dx.doi.org/10.1016/j.jiec.2012.08.027 
[22] Dar, B.A., Dadhwal, S., Singh, G., Garg, P., Sharma, P. and Singh, B. (2013) Vapour Phase Conversion of Glycerol to Acrolein over Supported Copper. Arabian Journal for Science and Engineering, 38, 37-40. http://dx.doi.org/10.1007/s13369-012-0395-y

[23] Dar, B.A., Mohsin, M., Basit, A. and Farooqui, M. (2011) Sand: A Natural and Potential Catalyst in Renowned Friedel Craft's Acylation of Aromatic Compounds. Journal of Saudi Chemical Society, 17, 177-180. http://dx.doi.org/10.1016/j.jscs.2011.03.004

[24] Dar, B.A., Singh, A., Sahu, A.K., Patidar, P., Chakraborty, A., Sharma, M. and Singh, B. (2012) Catalyst and SolventFree, Ultrasound Promoted Rapid Protocol for the One-Pot Synthesis of $\alpha$-Aminophosphonates at Room Temperature. Tetrahedron Letters, 53, 5497-5502. http://dx.doi.org/10.1016/j.tetlet.2012.07.123

[25] Dar, B.A., Sharma, M. and Singh, B. (2012) Ceria-Based Mixed Oxide Supported Nano-Gold as an Efficient and Durable Heterogeneous Catalyst for Oxidative Dehydrogenation of Amines to Imines Using Molecular Oxygen. Bulletin of Chemical Reaction Engineering \& Catalysis, 7, 79-84.

[26] Dar, B.A. and Farooqui, M. (2011) article title. Orbital: The Electronic Journal of Chemistry, 3, 89.

[27] Nikakhtari, H. and Hill, G.A. (2005) Enhanced Oxygen Mass Transfer in an External Loop Airlift Bioreactor Using a Packed Bed. Industrial \& Engineering Chemistry Research, 44, 1067-1072. http://dx.doi.org/10.1021/ie0494925

[28] Reddy, E.L., Karuppiah, J., Biju, V.M. and Subrahmanyam, Ch. (2013) Catalytic Packedbed Nonthermal Plasma Reactor for the Extraction of Hydrogen from Hydrogen Sulfide. International Journal of Energy Research, 37, 12801286.

[29] Bhalla, V., Carrara, S., Stagni, C. and Samori, B. (2010) Chip Cleaning and Regeneration for Electrochemical Sensor Arrays. Thin Solid Films, 518, 3360-3366. http://dx.doi.org/10.1016/j.tsf.2009.10.022

[30] Diaz, E., de Rivas, B., Lopez-Fonseca, R., Ordonez, S. and Gutierrez-Ortiz, J.I. (2006) Characterization of CeriaZirconia Mixed Oxides as Catalysts for the Combustion of Volatile Organic Compounds Using Inverse Gas Chromatography. Journal of Chromatography A, 1116, 230-239. http://dx.doi.org/10.1016/j.chroma.2006.03.043

[31] Avgouropoulosa, G., Ioannidesa, T. and Matralis, H. (2005) Influence of the Preparation Method on the Performance of $\mathrm{CuO}-\mathrm{CeO}_{2}$ Catalysts for the Selective Oxidation of CO. Applied Catalysis B: Environmental, 56, 87-93. http://dx.doi.org/10.1016/j.apcatb.2004.07.017

[32] Liu, L., Yao, Z., Liu, B. and Dong, L. (2010) Correlation of Structural Characteristics with Catalytic Performance of $\mathrm{CuO} / \mathrm{Ce}_{\mathrm{x}} \mathrm{Zr}_{1-\mathrm{x}} \mathrm{O}_{2}$ Catalysts for NO Reduction by CO. Journal of Catalysis, 275, 45-60. http://dx.doi.org/10.1016/j.jcat.2010.07.024

[33] Zhang, R., Teoh, W.Y., Amal, R., Chen, B. and Kaliaguine, S. (2010) Catalytic Reduction of NO by CO over Cu/ $\mathrm{Ce}_{\mathrm{x}} \mathrm{Zr}_{1-\mathrm{x}} \mathrm{O}_{2}$ Prepared by Flame Synthesis. Journal of Catalysis, 272, 210-219. http://dx.doi.org/10.1016/j.jcat.2010.04.001

[34] Liang, Q., Wu, X., Weng, D. and Lu, Z.X. (2008) Selective Oxidation of Soot over Cu Doped Ceria/Ceria-Zirconia Catalysts. Catalysis Communications, 9, 202-206. http://dx.doi.org/10.1016/j.catcom.2007.06.007

[35] Marban, G., Lopez, I. and Valdes-Solís, T. (2009) Preferential Oxidation of CO by $\mathrm{CuO}_{\mathrm{x}} / \mathrm{CeO}_{2}$ Nanocatalysts Prepared by SACOP. Mechanisms of Deactivation under the Reactant Stream. Applied Catalysis A: General, 361, 160-169. http://dx.doi.org/10.1016/j.apcata.2009.04.014

[36] Luo, M.F., Song, Y.P., Lu, J.Q., Wang, X.Y. and Pu, Z.Y. (2007) Identification of CuO Species in High Surface Area $\mathrm{CuO}-\mathrm{CeO}_{2}$ Catalysts and Their Catalytic Activities for CO Oxidation. Journal of Physical Chemistry C, 111, 1268612692. http://dx.doi.org/10.1021/jp0733217

[37] Zimmer, P., Tschöpe, A. and Birringer, R. (2002) Temperature-Programmed Reaction Spectroscopy of Ceria- and Cu/ Ceria-Supported Oxide Catalyst. Journal of Catalysis, 205, 339-345. http://dx.doi.org/10.1006/jcat.2001.3461

[38] Dong, X.F., Zou, H.B. and Lin, W.M. (2006) Effect of Preparation Conditions of $\mathrm{CuO}-\mathrm{CeO}_{2}-\mathrm{ZrO}_{2}$ Catalyst on CO Removal from Hydrogen-Rich Gas. International Journal of Hydrogen Energy, 31, 2337-2344. http://dx.doi.org/10.1016/j.ijhydene.2006.03.006

[39] Gutierrez-Ortiz, J.I., de Rivas, B., Lopez-Fonseca, R. and Gonzalez-Velasco, J.R. (2006) Catalytic Purification of Waste Gases Containing VOC Mixtures with Ce/Zr Solid Solutions. Applied Catalysis B, 65, 191-200. http://dx.doi.org/10.1016/j.apcatb.2006.02.001

[40] Deng, W.P., Tan, X., Fang, W., Zhang, Q.H. and Wang, Y. (2009) Conversion of Cellulose into Sorbitol over Carbon Nanotube-Supported Ruthenium Catalyst. Catalysis Letters, 133, 167-174. http://dx.doi.org/10.1007/s10562-009-0136-3

[41] Baek, G., You, S.J. and Park, E.D. (2012) Direct Conversion of Cellulose into Polyols over Ni/W/SiO $\mathrm{S}_{2}-\mathrm{Al}_{2} \mathrm{O}_{3}$. Bioresource Technology, 114, 684-690. http://dx.doi.org/10.1016/j.biortech.2012.03.059 
[42] Han, J.W. and Lee, H. (2012) Direct Conversion of Cellulose into Sorbitol Using Dual-Functionalized Catalysts in Neutral Aqueous Solution. Catalysis Communications, 19, 115-118. http://dx.doi.org/10.1016/j.catcom.2011.12.032

[43] Yang, P., Kobayashi, H., Hara, K. and Fukuoka, A. (2012) Phase Change of Nickel Phosphide Catalysts in the Conversion of Cellulose into Sorbitol. ChemSusChem, 5, 920-926. http://dx.doi.org/10.1002/cssc.201100498

[44] Ji, N., Zhang, T., Zheng, M., Wanga, A., Wanga, H., Wang, X., Shu, Y., Stottlemyer, A.L. and Chen, J.G. (2009) Catalytic Conversion of Cellulose into Ethylene Glycol over Supported Carbide Catalysts. Catalysis Today, 147, 77-85. http://dx.doi.org/10.1016/j.cattod.2009.03.012 
Scientific Research Publishing (SCIRP) is one of the largest Open Access journal publishers. It is currently publishing more than 200 open access, online, peer-reviewed journals covering a wide range of academic disciplines. SCIRP serves the worldwide academic communities and contributes to the progress and application of science with its publication.

Other selected journals from SCIRP are listed as below. Submit your manuscript to us via either submit@scirp.org or Online Submission Portal.
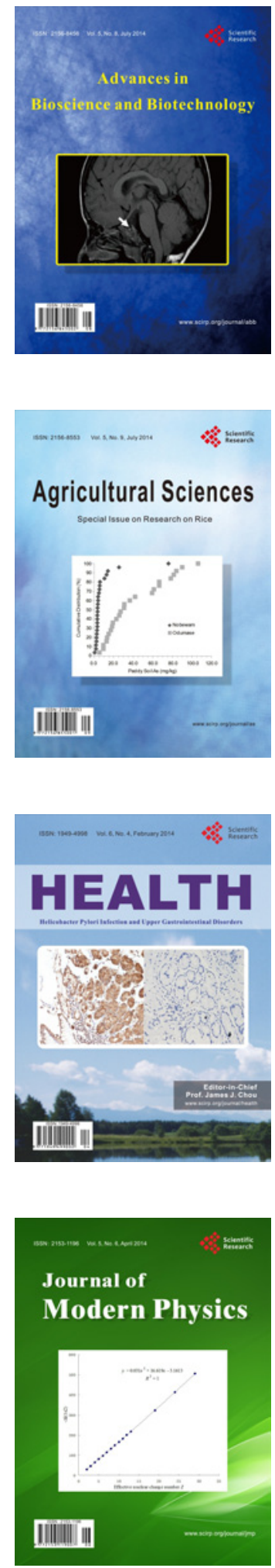
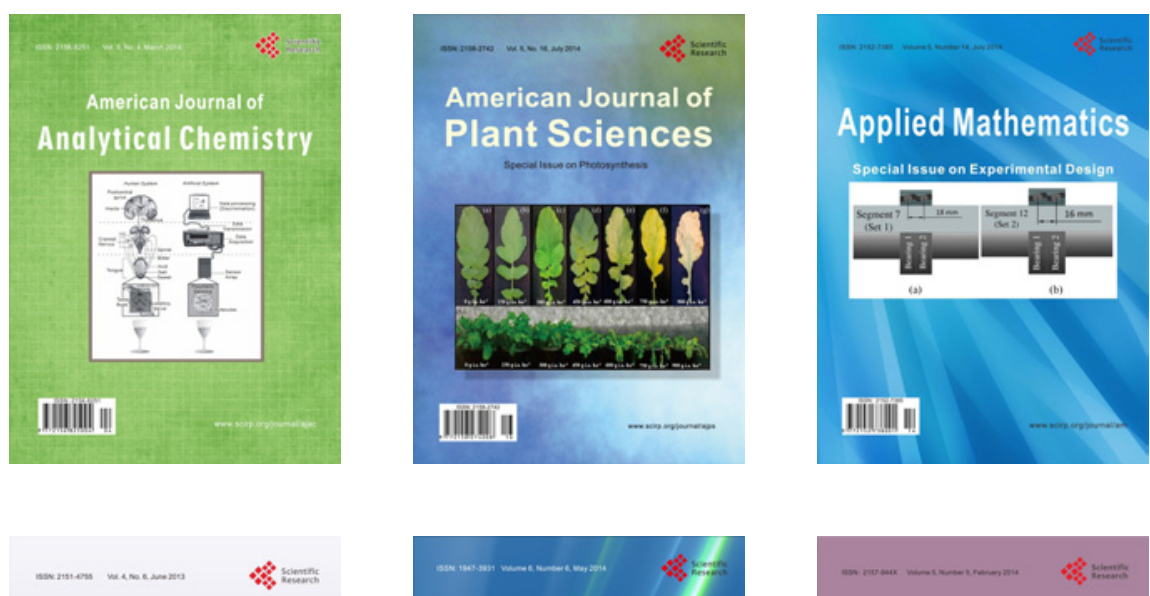

Creative Education
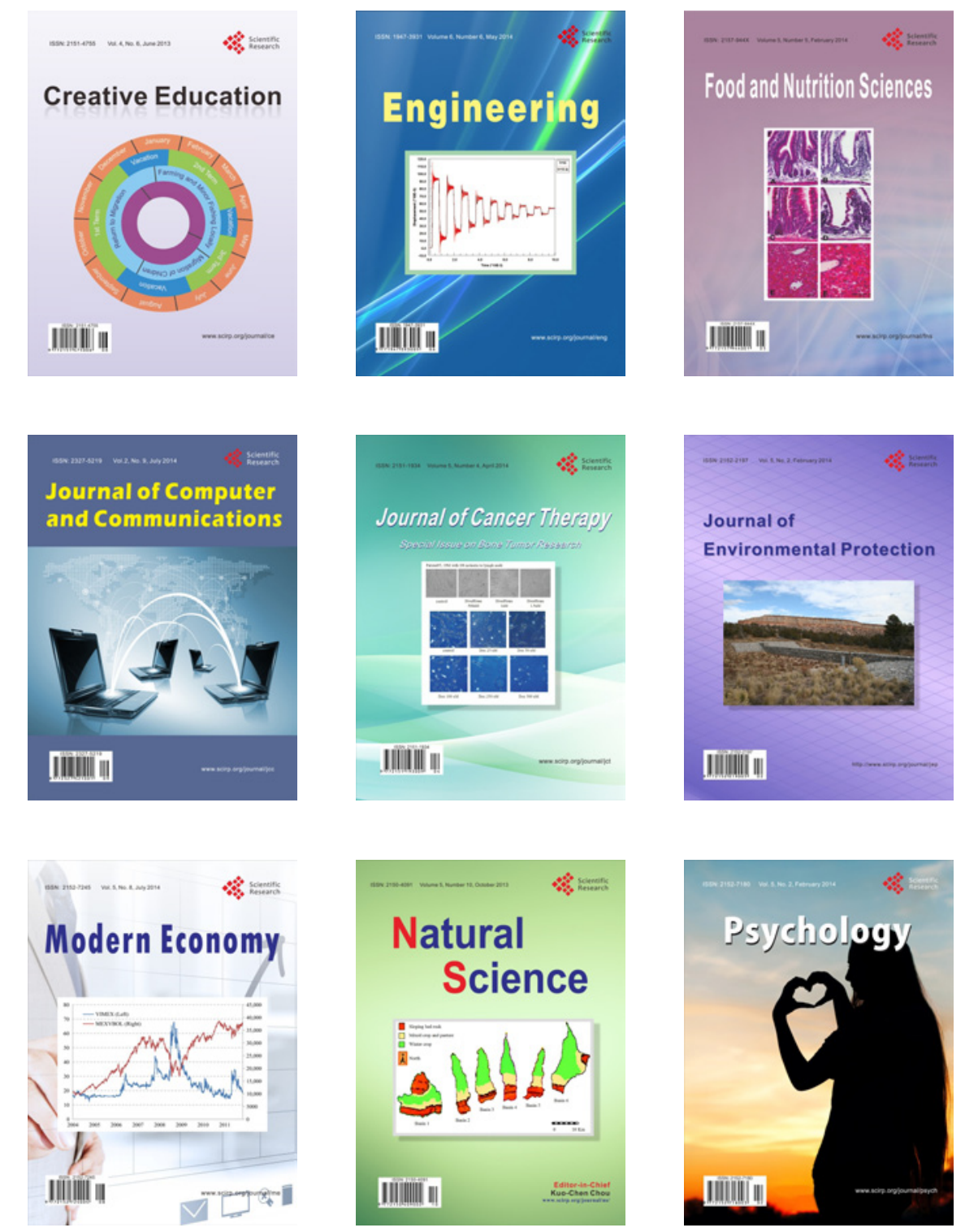